\title{
First record of the African spadefish, Tripterodon orbis Playfair, 1867 (family: Ephippidae) from the north-east coast of India
}

\author{
PRALAYA RANJAN BEHERA, SHUBHADEEP GHOSH AND M. SATISH KUMAR \\ Visakhapatnam Regional Centre of Central Marine Fisheries Research Institute, Visakhapatnam-530 003, India
}

\begin{abstract}
A single specimen of the African spadefish, Tripterodon orbis, was landed in a gill net operating off Visakhapatnam on 13 December 2013. The morphometric and meristic characters of the recorded specimen are described and discussed herein. This is the first occurrence of the species from the north-east coast of India, exhibiting an extension in distribution from the southern to the northern region, along the Bay of Bengal.
\end{abstract}

Keywords: range extension, African spadefish, Tripterodon orbis, Visakhapatnam

Submitted 25 September 2014; accepted 7 July 2015

\section{INTRDロUCTIDN}

The family Ephippidae, commonly known as spadefishes, comprises eight genera (Nelson, 2006) and 15 valid species (Eschmeyer \& Fong, 2014), mostly inhabiting coastal waters around reefs, up to a depth of $30 \mathrm{~m}$ (Nelson, 2006). The genus Platax is the most speciose, while the genus Tripterodon is monotypic (Jawad et al., 2012). The maximum length attained by Tripterodon orbis is $750 \mathrm{~mm}$ (Fischer \& Bianchi, 1984; Heemstra \& Heemstra, 2004), with common lengths reaching $300 \mathrm{~mm}$. They feed on rock and coral-dwelling organisms and their flesh is edible (Froese \& Pauly, 2014).

The species had earlier been reported from the Western Indian Ocean (Somalia, Kenya, south to Algoa Bay, South Africa), from the Red sea and from the eastern Indian Ocean (Andaman and Nicobar Islands, and Sri Lanka) (Froese \& Pauly, 2014). Indrasenan (1960) had also reported the occurrence of Tripterodon orbis from Rameswaram Island, in the Gulf of Mannar, south-east coast of India. However, this is the first occurrence of the species at Visakhapatnam along the north-east coast of India, a significant extension of its distribution from the southern to the northern region, along the Bay of Bengal.

\section{MATERIAL AND METHDDS}

On 13 December 2013, one specimen (Figure 1) was collected from a gill net operating at depths between 40 and $70 \mathrm{~m}$, about $20 \mathrm{~km}$ north of Visakhapatnam Fishing Harbour (Figure 2).

Corresponding author:

P.R. Behera

Email: beherapralaya213@gmail.com
The specimen was identified as Tripterodon orbis based on diagnostic characters described by Smith (1986). Measurements were taken using a digital Vernier calliper to the nearest $0.1 \mathrm{~mm}$ and were expressed as a percentage of the standard length (SL). The morphometric and meristic data of the recorded species were compared with the holotype (Playfair \& Gunther, 1867). The identified specimen (whole fish) was initially fixed in $10 \%$ formaldehyde and later preserved in $70 \%$ ethanol, after a thorough washing. The specimen was deposited in the National Marine Biodiversity Referral Museum at the Central Marine Fisheries Research Institute, Kochi (Accession No. GB 31.60.5.6).

\section{RESULTS AND DISCUSSIDN}

SYSTEMATICS

Order PERCIFORMES, Bleeker, 1939

Family EPHIPPIDAE

Genus Tripterodon Playfair, 1867

Species Tripterodon orbis Playfair, 1867

\section{MATERIAL EXAMINED}

Single specimen of Tripterodon orbis (gill net, Visakhapatnam, water depth 40-70 m), coll. by P.R. Behera, 13 December 2013.

Fin formula: D IX, 21; P 18; V I, 5; A III, 16; C 17; L. lat. 52; L. trans. $11 / 28$

The body is compressed and greatly elevated and the upper profile is strongly curved. The upper profile descends from the origin of the dorsal fin to the snout very abruptly, forming a rather prominent protuberance between the eyes. The greatest height of the body is below the fifth dorsal spine (60.7\% SL) and the length of the head is about $26.2 \%$ of SL. The eye is 


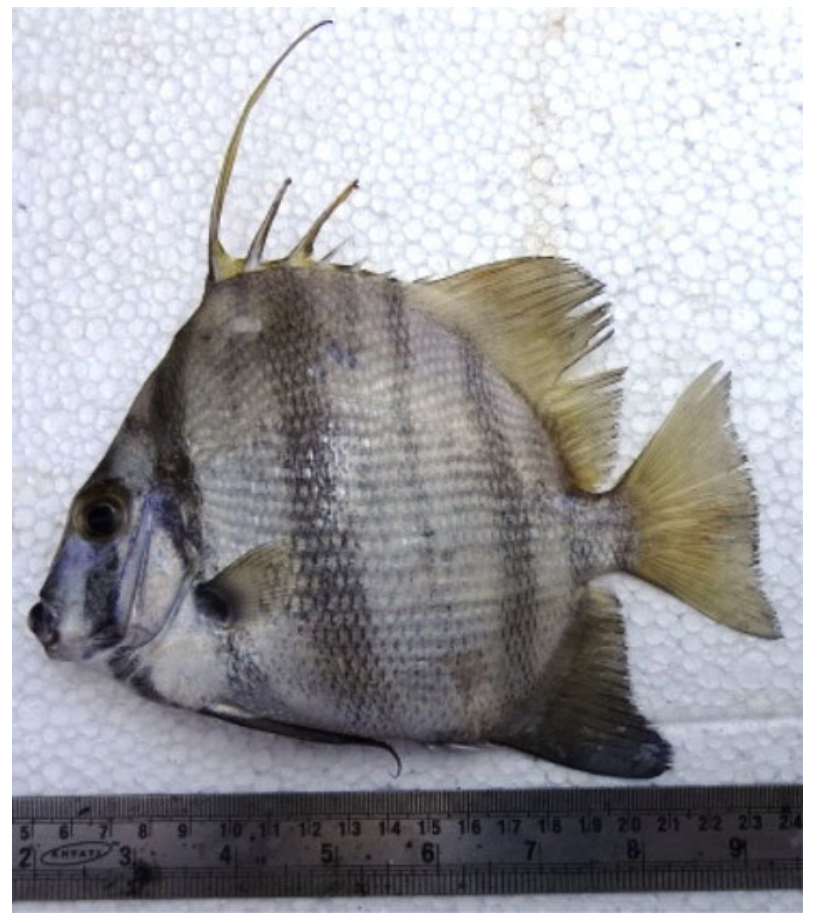

Fig. 1. African spadefish, Tripterodon orbis Playfair, 1867 at Visakhapatnam.

situated high up in the head, with diameter about $72.2 \%$ of the snout length and occupying $27.1 \%$ of the head length. Mouth is small, slightly protractile and terminal with thick lips. The mouth gape is small, with the upper maxillary positioned vertically from the posterior nostril. The interorbital space is concave. Top of head is without scales. There are five series of scales on the cheek. The posterior limb of the preoperculum is naked and the entire operculum is covered with scales. In the upper jaw, there are four and in the lower jaw, there are three series of large, broad, flat, moveable, tricuspid teeth.

The dorsal spines are very broad and flat, and rather feeble. The first and second dorsal spines are minute, while the third, fourth and fifth are formed into long filaments, which are about $47.0,18.5$ and $17.2 \%$ of the head length. The sixth is equal to the diameter of the eye; the seventh and eighth are short with lengths progressively decreasing. The ninth, which is regarded as belonging to the soft portion, is shorter than the sixth. All these spines are inserted in and are received within a deep scaly sheath. The soft portion of the spines is scaly and the length of its base is greater than that of the spinous portion. The caudal fin is emarginated. The anal fin is elevated, while its edge is emarginated. The anal fin spines are short, strong and rather remote from each other. The second and third spines are nearly equal in length and their soft portion is covered with scales. The third anal ray is longer than the longest of the dorsal. Pectoral fin is obtusely pointed, and much shorter than the ventral. Ventral fin is long, the first ray being produced into a filament, which reaches to the anal. Detailed morphometric and meristic characters of the species are presented in Table 1.

The colour of the body is silvery grey, with about nine indistinct darker cross bands. The first (through the eye) and the second (from the top of the interparietal crest, passing over the superior angle of the operculum and root of the pectorals) bands are more distinct than the others. Caudal and dorsal fins are yellowish, while pelvic and anal fins are blackish.

The present record matches well with the earlier description of the same species from Oman waters (Jawad et al., 2012). This species differs from Ephippus orbis in its body shape being more oblong, the presence of large and tricuspid teeth, its large eye diameter, measuring half the distance from mouth to eye, its scaleless head top and by the presence of nine indistinct vertical bars. It differs from species belonging to the Drepanidae family in having a short pectoral fin, a nonprotrusible mouth, and long $3 \mathrm{rd}$ and 4 th dorsal fin spines. It differs from the members of the family Scatophagidae in having three anal spines and in having a vertical head profile (Fischer \& Bianchi, 1984). The morphometric and meristic characters of the specimen agree well with earlier descriptions reported by previous authors, albeit with slight

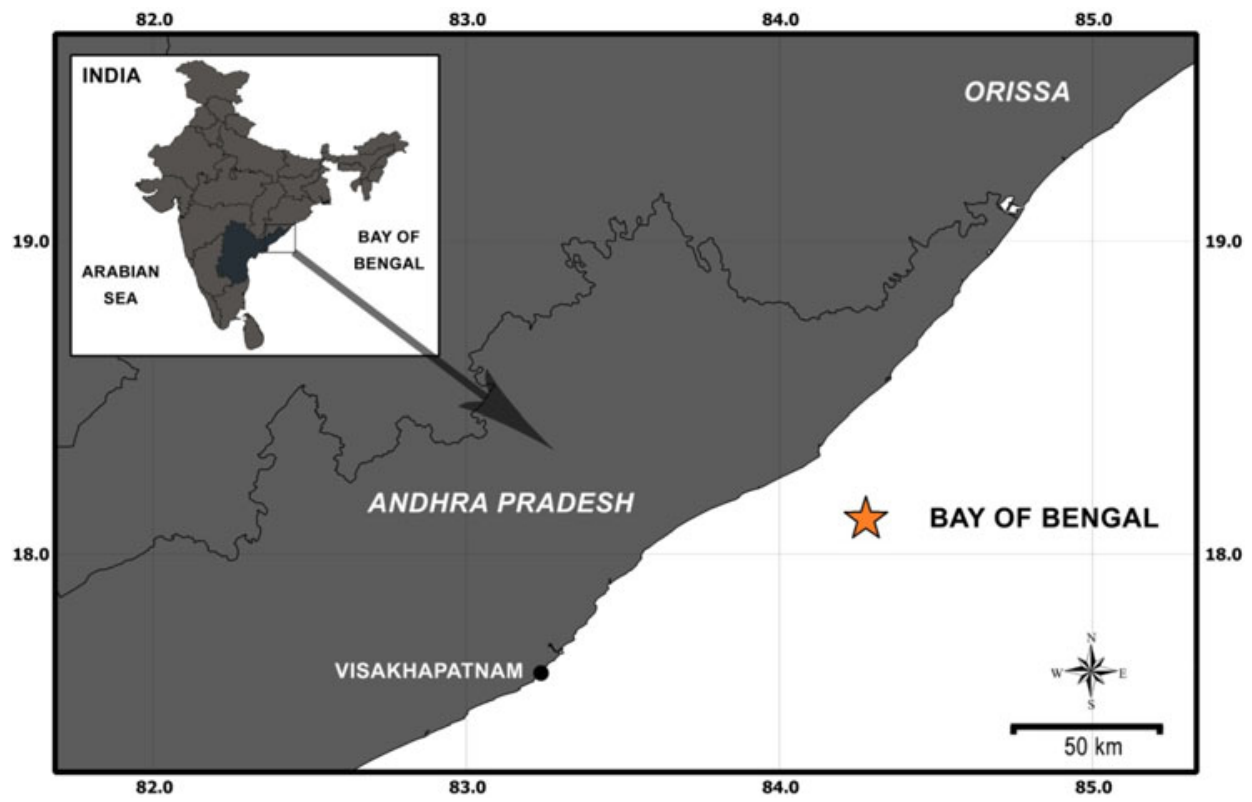

Fig. 2. Capture location (orange star) of Tripterodon orbis Playfair, 1867 along the north-east coast of India. 
Table 1. Morphometric measurements of Tripterodon orbis landed at Visakhapatnam.

\begin{tabular}{|c|c|c|}
\hline $\begin{array}{l}\text { Morphometric } \\
\text { characters }\end{array}$ & $\begin{array}{r}\text { Specimen } \\
\text { measurements } \\
(\mathrm{mm})\end{array}$ & $\begin{array}{r}\% \text { of standard } \\
\text { length }\end{array}$ \\
\hline Total length & 183 & - \\
\hline Standard length & 151 & - \\
\hline Body depth & 111 & 73.50 \\
\hline Head length & 48 & 31.78 \\
\hline Eye diameter & 13 & 8.60 \\
\hline Inter orbital width & 16 & 10.59 \\
\hline Suborbital length & 20 & 13.24 \\
\hline Snout length & 18 & 11.92 \\
\hline Maxillary length & 10 & 6.62 \\
\hline Length of dorsal fin base & 103 & 68.21 \\
\hline Spinous dorsal fin base length & 52 & 34.43 \\
\hline Soft dorsal fin base length & 51 & 33.77 \\
\hline Dorsal fin spine length (1st) & 2 & 1.32 \\
\hline Dorsal fin spine length (2nd) & 5 & $3 \cdot 31$ \\
\hline Dorsal fin spine length ( $3 \mathrm{rd})$ & 71 & 47.01 \\
\hline Dorsal fin spine length (4th) & 28 & 18.54 \\
\hline Dorsal fin spine length ( 5 th) & 26 & 17.21 \\
\hline Dorsal fin spine length (6th) & 13 & 8.60 \\
\hline Dorsal fin spine length ( 7 th) & 7 & 4.63 \\
\hline Dorsal fin spine length (8th) & 6 & 3.97 \\
\hline Dorsal fin spine length (9th) & 7 & 4.63 \\
\hline Longest soft dorsal ray length & 42 & 27.81 \\
\hline Length of pectoral fin & 29 & 19.20 \\
\hline Length of pectoral fin base & 11 & 7.28 \\
\hline Length of pelvic fin spine & 42 & 27.81 \\
\hline Length of pelvic fin soft ray & 52 & 34.43 \\
\hline Length of anal spine (1st) & 5 & 3.31 \\
\hline Length of anal spine (2nd) & 13 & 8.60 \\
\hline Length of anal spine (3rd) & 13 & 6.62 \\
\hline Length of anal fin soft ray & 44 & 29.13 \\
\hline Caudal peduncle length & 13 & 8.60 \\
\hline Caudal peduncle height & 25 & 16.55 \\
\hline Caudal fin height & 72 & 47.68 \\
\hline Caudal fin length & 24 & 15.89 \\
\hline Predorsal length & 62 & 41.05 \\
\hline Prepectoral length & 49 & 32.45 \\
\hline Prepelvic length & 48 & 31.78 \\
\hline Preanal length & 96 & 63.57 \\
\hline Pre orbital length & 26 & 17.21 \\
\hline Post orbital length & 10 & 6.62 \\
\hline Total weight (g) & 230 & - \\
\hline
\end{tabular}

variations in a few of the characters (pectoral fin count, LI scales and proportion of eye diameter to interorbital space), which could be attributed to the differing geographic locations (Table 2).

The occurrence of $T$. orbis has previously been reported from the Andaman and Nicobar Islands (Froese \& Pauly, 2014) and from Rameswaram Island in the Gulf of Mannar, south-east coast of India (Indrasenan, 1960). The present occurrence from the waters of Visakhapatnam indicates a northward range extension of the distribution of the African spadefish, from the Gulf of Mannar and the Andaman and Nicobar Islands in the southern Bay of Bengal to Visakhapatnam in the northern Bay of Bengal. However, subsequent landings of the species are required for confirming their true range of extension. Similarly, an increase in the distribution range from the southern to the northern latitudes along the east and west coast of India in the last couple of
Table 2. Comparison of the morphometric and meristic characters of Tripterodon orbis from Visakhapatnam with the holotype. TL, total length; SN, Snout length; HL, Head length; Lat., Latitudinal; Trans., Transeverse.

\begin{tabular}{lrr}
\hline Characters & $\begin{array}{r}\text { Playfair, 1867 } \\
\text { (Holotype) }\end{array}$ & CMFRI GB. 31. 6o. \\
\hline Morphometric & & $\mathbf{5 . 6}$ \\
Body depth (\%TL) & 50 & 60.65 \\
Head length (\%TL) & 46.66 & 26.22 \\
Eye diameter (\%SN) & 50 & 72.22 \\
Eye diameter (\%HL) & 35 & 27.08 \\
Meristic characters & - & - \\
Dorsal fin & $\mathrm{IX}, 20$ & $\mathrm{IX}, 21$ \\
Anal fin & $\mathrm{III}, 16$ & $\mathrm{III}, 16$ \\
Pectoral fin & - & 18 \\
Ventral fin & - & $\mathrm{I}, 5$ \\
Caudal fin & - & 17 \\
LI scales (Lat.) & 52 & 52 \\
LI scales (Trans.) & $11 / 28$ & $11 / 28$ \\
\hline
\end{tabular}

decades has been recorded for Indian oil sardine and Indian mackerel (Vivekanandan et al., 2009). A similar range extension of distribution from the south to the north region along the Bay of Bengal has previously been reported for Pacific Gregory, Stegastes fasciolatus (Behera et al., 2014). This broadening in distribution could be attributed to the rising water temperatures along the east coast of India, which are increasing by $0.04{ }^{\circ} \mathrm{C}$ each decade (Vivekanandan et al., 2009). The sea surface temperature has shown a progressive increase in the Bay of Bengal since the 1950s, resulting in changes/shifts in fish communities of the area (Vivekanandan et al., 2009). With gradual warming, the waters of the northern Bay of Bengal are now conducive for the survival of a wide range of species, as evident in the present study and as reported by previous authors (Vivekanandan et al., 2009; Behera et al., 2014).

\section{ACKNDWLEDGEMENTS}

The authors are grateful to the Director of the Central Marine Fisheries Research Institute, Kochi for his constant support and encouragement. The authors are greatly indebted to Dr (Mrs) Muktha Menon, for critically reviewing the literary sections of this manuscript.

\section{REFERENCES}

Behera P.R., Muktha M. and Shubhadeep G. (2014) Occurrence of Pacific gregory, Stegastes fasciolatus (Ogilby 1889) (Family Pomacentridae) off Visakhapatnam, east coast of India. Marine Biodiversity Record 7, e122, doi: 10.1017/S175526721400102X.

Eschmeyer W.N. and Fong J.D. (2014) Catalog of fishes, version (4/2013). Available at: http://www.research.calacademy.org (accessed 04 December 2014).

Fischer W. and Bianchi G. (1984) FAO species identification sheets for fishery purposes. Western Indian Ocean (Fishing area 51). Prepared and printed with the support of the Danish International Development Agency (DANIDA), Vols. 1-6. Rome: FAO. 
Froese R. and Pauly D. (eds) (2014) FishBase, version (04/2014). Available at: http://www.fishbase.org (accessed 04 July 2014).

Heemstra P.C. \& Heemstra E. (2004) Coastal fishes of southern Africa. Grahamstown: NISC and SAIAB, pp. i-xxiv, 1-488.

Indrasenan A. (1960) On the occurrence of the Platacid fish, Tripterodon orbis in Indian waters. Journal of the Marine Biological Association of India $2,26$.

Jawad L., Al-Mamry J. and Al-Shogebai S. (2012) Confirmation of the presence of the African spadefish, Tripterodon orbis Playfair, 1867 (Perciformes: Ephippidae) in the Arabian Sea coast of Oman. Annali del Museo Civico di Storia Naturale di Ferrara 14/15, 99-102.

Nelson J.S. (2006) Fishes of the world, 4 th edn. New York: John Wiley and Sons, Inc., $601 \mathrm{pp}$.

Playfair R.L. and Günther A.C.L.G. (1867) The fishes of Zanzibar, with a list of the fishes of the whole east coast of Africa. London: John van Voorst, xiv $+153 \mathrm{pp}$.
Smith M.M. (1986) Ephippidae. In Smith M.M. and Heemstra P.C. (eds) Smiths' sea fishes. Berlin: Springer-Verlag, pp. 605-607.

and

Vivekanandan E., Rajagopalan M. and Pillai N.G.K. (2009) Recent trends in sea surface temperature and its impact on oil sardine. In Aggarwal P.K. (ed.) Impact, adaptation and vulnerability of Indian agriculture to climate change. New Delhi: Indian Council of Agricultural Research, pp. 89-92.

\section{Correspondence should be addressed to:}

P.R. Behera

Visakhapatnam Regional Centre of Central

Marine Fisheries Research Institute

Oceanview Layout, Pandurangapuram

A.U. Campus, Visakhapatnam-530 003, India

email: beherapralaya213@gmail.com 